\title{
Polymorphisms of VEGFA gene and susceptibility to hemorrhage risk of brain arteriovenous malformations in a Chinese population
}

\author{
Zhi-ping GONG ${ }^{1}$, Ni-dan QIAO ${ }^{2}$, Yu-xiang GU², Jian-ping SONG ${ }^{2}$, Pei-liang LI $^{2}$, Hui-jia QIU², Wei-wei FAN ${ }^{3}$, Ying MAO ${ }^{2}$, Hong- \\ yan $\mathrm{CHEN}^{3, *}$, Yao $\mathrm{ZHAO}^{2, *}$ \\ ${ }^{1}$ Operation Room, First Affiliated Hospital, College of Medicine, Zhejiang University, Hangzhou 310003, China; ${ }^{2}$ Department of Neuro- \\ surgery, HuaShan Hospital, Shanghai Medical College, Fudan University, Shanghai 200040, China; ${ }^{3}$ State Key Laboratory of Genetic \\ Engineering and MOE Key Laboratory of Contemporary Anthropology, School of Life Sciences, Fudan University, Shanghai 200433, \\ China
}

Aim: To evaluate the influence of the vascular endothelial growth factor A (VEGFA) polymorphisms on risk of presentation with intracerebral hemorrhage (ICH).

Methods: Nine selected VEGFA single-nucleotide polymorphisms (SNPs) were genotyped in 311 patients with brain arteriovenous malformations (BAVM) in a Chinese population. Associations between individual SNPs/haplotypes and the hemorrhage risk of BAVMs were evaluated using logistic regression analysis.

Results: In the single-locus analysis, rs1547651 was associated with increased risk of ICH (adjusted OR=2.11, 95\% Cl=1.01-4.42 compared with the AA genotype). In particular, an increased risk for ICH was associated with this variant in female patients (adjusted $\mathrm{OR}=3.21$, and 95\% $\mathrm{Cl}=0.99-10.36$ ). Haplotype-based analyses revealed that haplotype 'GC' in block 1 and haplotype 'ACC' in block 2 were associated with a $30 \%-38 \%$ reduction in the risk of $\mathrm{ICH}$ in patients with BAVMs compared to the most common haplotype $\left(P_{\text {sim }}=0.033\right.$ and $P_{\text {sim }}=0.005$, respectively). The protective effect of haplotype 'ACC' in block 2 was more evident in male patients and subjects with $\mathrm{BAVMs}$ of a size $\geq 3 \mathrm{~cm}$ (adjusted $\mathrm{OR}=0.57,95 \% \mathrm{Cl}=0.34-0.97$ and adjusted $\mathrm{OR}=0.57,95 \% \mathrm{Cl}=0.31-0.86, \mathrm{respectively}$ ). Conclusion: The results suggest that VEGFA gene variants may contribute to ICH risk of BAVM.

Keywords: brain arteriovenous malformations; cerebral hemorrhage; vascular endothelial growth factor A (VEGFA); single-nucleotide polymorphism (SNPs)

Acta Pharmacologica Sinica (2011) 32: 1071-1077; doi: 10.1038/aps.2011.76; published online 27 Jun 2011

\section{Introduction}

Brain arteriovenous malformations (BAVMs) are a common cause of intracerebral hemorrhage (ICH), especially in young adults $^{[1]}$. An accurate estimate of ICH risk in patients harboring BAVMs is needed to help guide clinical management. Although features of BAVM associated with $\mathrm{ICH}$ have been identified, additional robust and reproducible indices are still needed. Genetic variation may influence the pathogenesis and the clinical course of BAVMs. The identification of genetic polymorphisms associated with clinical manifestations would facilitate risk stratification as well as illuminate the underlying

\footnotetext{
* To whom correspondence should be addressed.

E-mail chenhy@fudan.edu.cn (Hong-yan CHEN); zhaoyaohs@hotmail.com (Yao ZHAO)

Received 2011-03-30 Accepted 2011-05-11
}

biology ${ }^{[2]}$.

Vascular endothelial growth factor A (VEGFA) plays an important role in the migration, proliferation and survival of endothelial cells ${ }^{[3,4]}$. It has been hypothesized to be involved in the pathogenesis of cancer metastasis, retinopathy, agerelated macular degeneration, rheumatoid arthritis and psoriasis $^{[5-7]}$. Molecular characterization of BAVM tissue has provided evidence for the involvement of angiogenesis, and Hashimoto et $a l^{[8]}$ have shown that a prominent feature of the BAVM tissue is relative overexpression of VEGFA at both the mRNA and protein levels. Furthermore, VEGFA may contribute to the hemorrhagic tendency of BAVMs, as extrapolated from animal models ${ }^{[9]}$.

The VEGFA gene is located on chromosome 6p21.3 and comprises a $14 \mathrm{~kb}$ coding region with eight exons. Over thirty single nucleotide polymorphisms (SNPs) have been described 
in the region of the VEGFA. To date, several case-control studies have confirmed the association of VEGFA SNPs with a risk of developing several types of tumors ${ }^{[10-13]}$ and other diseases ${ }^{[14,15]}$; however, to our knowledge, there is little data on the role of VEGFA SNPs in relation to ICH risk in patients with BAVMs, in spite of the importance of VEGFA gene in the hemorrhagic tendency of BAVMs. Because of the dearth of knowledge in this area, we evaluated both potential functional SNPs and tag SNPs spanning the VEGFA for effects on the risk of presentation with $\mathrm{ICH}$.

\section{Materials and methods BAVM sample population}

Using the same recruitment method as described previously ${ }^{[16]}$, we recruited 311 patients diagnosed with incident BAVM (as demonstrated by pathology or angiography), all of whom were genetically unrelated ethnic Han Chinese. These patients were recruited between January 2004 and December 2007 at Huashan Hospital, Fudan University (Shanghai, China). Patients with a family history or diagnosis of hereditary hemorrhagic telangiectasia (HHT) were excluded. Patients with signs of new intracranial hemorrhage on computed tomography (CT) or magnetic resonance imaging (MRI) were defined as ICH. Patients (symptomatic or not), who had nonhemorrhagic intracranial lesions initially detected by CT scan or MRI and were proven to harbor BAVMs by angiography were coded as unruptured cases. The BAVM size and venous drainage pattern were determined by angiography and were classified using standard guidelines ${ }^{[17]}$. Each participant provided informed consent, and the studies were approved by the Human Subjects Review Committee of Huashan Hospital, Fudan University.

\section{Polymorphism selection and genotyping}

We selected tagging SNPs (tSNPs) in the VEGFA gene (6p21.3, NT_007592.14) with genotype data of Han Chinese from the International HapMap Project (HAPMAP), Public Release\#20/ Phase II on April 7th, 2007 (http:/ / www.hapmap.org). tSNPs were selected to cover the whole VEGFA gene. tSNPs with a minor allele frequency (MAF) greater than 0.05 (based on pairwise LD analysis) were selected to capture unmeasured SNPs with a minimum $r^{2}>0.8$. In addition, four potentially functional SNPs (rs1547651, rs2010963, rs1413711, and rs3025039) in VEGFA that were identified in previous reports were also included in this study. As a result, nine SNPs of the VEGFA were investigated.

We used white blood cell fractions from whole blood samples for the extraction of genomic DNA using the Qiagen Blood Kit (Qiagen, Chatsworth, CA, USA). Genotyping was performed with the MassARRAY iPLEX platform (Sequenom, San Diego, CA, USA) using an allele-specific MALDI-TOF mass spectrometry assay ${ }^{[18]}$. Primers for amplification and extension reactions were designed using the MassARRAY Assay Design Version 3.1 software (Sequenom), and SNP genotypes were obtained according to the iPLEX protocol provided by the manufacturer. We examined the quality of the genotyping with a detailed QC procedure that ensured a $>95 \%$ successful call rate with duplicate calling of genotypes, internal positive control samples and Hardy-Weinberg Equilibrium (HWE) testing. The consistency rate observed in these duplicated samples was $100 \%$.

\section{Statistical analyses}

Genotype frequencies in ICH and unruptured cases were compared using a $\chi^{2}$-test. Estimate odds ratios (ORs) and $95 \%$ confidence intervals (CIs) were calculated by unconditional logistic regression with adjustments for age and gender. Akaike's information criterion (AIC) was employed to determine the best fitting model for each SNP ${ }^{[19]}$. The issue of multiple tests was controlled with 10000 time permutation tests. Pairwise linkage disequilibrium (LD) among the markers was examined using Lewontin's standardized coefficient $D^{\prime}$ and LD coefficient $r^{2}$ [20]. Haplotype blocks were defined by Haploview V4.1, as detailed by Gabriel et al ${ }^{[21]}$. PHASE 2.0 was used to infer the haplotype frequencies based on the observed genotypes $^{[22]}$. All the statistical analyses were performed using SPSS17.0 software with two-sided tests and a significance level set at 0.05 , unless otherwise indicated.

\section{Results}

\section{Characteristics of study participants}

Demographic and clinical characteristics of the patients with BAVMs are shown in Table 1. Of the 311 patients genotyped, $58.2 \%$ presented with hemorrhage, and $41.8 \%$ presented with unruptured BAVMs. The ages (mean \pm SD) of the patients were $33 \pm 14$ years in unruptured cases and $30 \pm 15$ years in ICH cases, with males accounting for $61.5 \%$ of unruptured cases and $55.8 \%$ of ICH cases. ICH presentation was not significantly associated with gender $\left(X^{2}, P=0.312\right)$ or age at diagnosis ( $t$ test, $P=0.063)$, but it was associated with deep venous drainage $\left(\chi^{2}\right.$, $P<0.001)$ and small BAVM size $\left(\chi^{2}, P<0.001\right)$.

Table 1. Demographics and BAVM characteristics.

\begin{tabular}{|c|c|c|c|c|c|c|}
\hline & ruptured & $\%$ & $\mathrm{ICH}$ & $\%$ & Total & $P$ \\
\hline \multicolumn{7}{|l|}{ Demographics } \\
\hline Total BAVM cases & 130 & $41.8 \%$ & 181 & $58.2 \%$ & 311 & \\
\hline \multicolumn{7}{|l|}{ Age at diagnosis } \\
\hline \multicolumn{3}{|c|}{ Mean age $\pm S D$, year $33 \pm 14$} & \multicolumn{2}{|l|}{$30 \pm 15$} & $31 \pm 15$ & \multirow[t]{2}{*}{0.063} \\
\hline$n$ & 130 & & 181 & & 311 & \\
\hline \multicolumn{7}{|l|}{ Gender } \\
\hline Female & 50 & $38.5 \%$ & 80 & $44.2 \%$ & 130 & \multirow[t]{2}{*}{0.312} \\
\hline Male & 80 & $61.5 \%$ & 101 & $55.8 \%$ & 181 & \\
\hline \multicolumn{7}{|c|}{ BAVM characteristics } \\
\hline \multirow[t]{2}{*}{ BAVM size } & 19 & $18.6 \%$ & 83 & $81.4 \%$ & 102 & \multirow[t]{2}{*}{$7.2 \times 10^{-9}$} \\
\hline & 111 & $53.1 \%$ & 98 & $46.9 \%$ & 209 & \\
\hline \multicolumn{7}{|l|}{ Venous drainage } \\
\hline Exclusively deep & 25 & $19.2 \%$ & 108 & $59.7 \%$ & 133 & \multirow[t]{2}{*}{$8.78 \times 10^{-24}$} \\
\hline Any superficial & 105 & $80.8 \%$ & 73 & $40.3 \%$ & 178 & \\
\hline
\end{tabular}


Analysis of single SNPs association with ICH risk in patients with BAVMs

In the single locus analysis, the genotype frequency of the rs1547651 and rs3025030 SNPs was significantly different between unruptured cases and ICH cases $\left(\chi^{2}\right.$, uncorrected $P=0.049$ and $P=0.047$, respectively); the association of rs1547651 still remained after the logistic regression analysis was adjusted for age and gender (adjusted OR=2.11; 95\% $\mathrm{CI}=1.01$ to 4.42 compared with the AA genotype). The remaining 7 SNPs did not reach the statistically significant level (Table 2).

Table 2. Frequency of the distribution of VEGFA SNP genotypes and their association with risk of hemorrhagic presentation.

\begin{tabular}{|c|c|c|c|c|c|c|c|}
\hline Genetic model & $\begin{array}{l}\text { Location in } \\
\text { gene region }\end{array}$ & Genotype & $\begin{array}{l}\text { Unruptured } \\
\text { № (\%) }\end{array}$ & $\mathrm{ICH}$ № (\%) & $\begin{array}{l}P \text { value } \\
X^{2} \text { test }\end{array}$ & $\begin{array}{l}\text { Adjusted OR } \\
\qquad(95 \% \mathrm{Cl})^{\mathrm{a}}\end{array}$ & $P$ value \\
\hline \multicolumn{8}{|l|}{ Genotype: } \\
\hline rs1547651 & Promoter & & & & 0.049 & & \\
\hline- & & $\mathrm{A} / \mathrm{A}$ & 115 (91.3\%) & 149 (83.2\%) & & 1.00 (reference) & \\
\hline rs2010963 & & $\mathrm{CC}$ & $40(32.0 \%)$ & 52 (30.1\%) & & 1.00 (reference) & \\
\hline \multirow[t]{2}{*}{ Codominant } & & CG & $66(52.8 \%)$ & 82 (47.4\%) & & $0.95(0.56-1.61)$ & 0.845 \\
\hline & & GG & 19 (15.2\%) & 39 (22.5\%) & & $1.54(0.77-3.07)$ & 0.221 \\
\hline Dominant & & $\mathrm{CG} / \mathrm{CC}$ & $106(84.8 \%)$ & $134(77.5 \%)$ & & $0.63(0.34-1.16)$ & 0.535 \\
\hline rs1413711 & Intron_1 & & & & 0.282 & & \\
\hline \multirow[t]{2}{*}{ rs833069 } & Intron_2 & & & & 0.117 & & \\
\hline & & AA & $36(29.8 \%)$ & $44(25.6 \%)$ & & 1.00 (reference) & \\
\hline \multirow[t]{2}{*}{ Codominant } & & $A G$ & $67(55.4 \%)$ & $88(51.2 \%)$ & & $1.05(0.61-1.82)$ & 0.856 \\
\hline & & GG & $18(14.8 \%)$ & 40 (23.2\%) & & $1.78(0.87-3.63)$ & 0.116 \\
\hline \multirow[t]{2}{*}{ Recessive } & & $\mathrm{AA} / \mathrm{AG}$ & $103(85.1 \%)$ & $132(76.7 \%)$ & & 1.00 (reference) & \\
\hline & & $\mathrm{G} / \mathrm{G}$ & $18(14.9 \%)$ & 40 (23.3\%) & & $0.58(0.31-1.08)$ & 0.081 \\
\hline \multirow[t]{2}{*}{ rs3024994 } & Intron_2 & & & & 0.203 & & \\
\hline & & $\mathrm{CC}$ & $116(91.3 \%)$ & 153 (86.9\%) & & 1.00 (reference) & \\
\hline \multirow[t]{2}{*}{ Codominant } & & $\mathrm{CT}$ & $11(8.7 \%)$ & $22(12.5 \%)$ & & $1.51(0.70-3.26)$ & 0.298 \\
\hline & & $\mathrm{TT}$ & $0(0 \%)$ & $1(0.6 \%)$ & & 1.25E9 (0.0-) & 1 \\
\hline Log-additive & & - & - & - & & $0.62(0.30-1.30)$ & 0.2 \\
\hline rs3025030 & & GG & $81(64.3 \%)$ & $131(74.0 \%)$ & & 1.00 (reference) & \\
\hline Codominant & & $\mathrm{GC}$ & 39 (30.9\%) & 42 (23.7\%) & & $0.70(0.41-1.18)$ & 0.181 \\
\hline & & $\mathrm{CC}$ & $6(4.8 \%)$ & $4(2.3 \%)$ & & $0.42(0.11-1.55)$ & 0.194 \\
\hline Log-additive & & - & - & - & & $1.47(0.96-2.26)$ & 0.077 \\
\hline rs3025035 & Intron_7 & & & & 0.211 & & \\
\hline & & $\mathrm{CC}$ & 95 (75.4\%) & $122(70.1)$ & & 1.00 (reference) & \\
\hline Codominant & & $\mathrm{TC}$ & $30(23.8)$ & 47 (27.0\%) & & $1.19(0.70-2.03)$ & 0.523 \\
\hline & & $\mathrm{TT}$ & $1(0.8 \%)$ & $5(2.9 \%)$ & & $3.84(0.44-33.96)$ & 0.226 \\
\hline Recessive & & $\mathrm{CC} / \mathrm{CT}$ & $125(99.2 \%)$ & $169(97.1 \%)$ & & 1 (reference) & \\
\hline & & $\mathrm{TT}$ & $1(0.8 \%)$ & 5 (2.9\%) & & $0.27(0.03-2.40)$ & 0.19 \\
\hline rs3025039 & Exon_8 & & & & 0.188 & & \\
\hline & & $\mathrm{CC}$ & $83(67.4 \%)$ & $129(73.7 \%)$ & & 1.00 (reference) & \\
\hline Codominant & & $\mathrm{CT}$ & $35(28.5 \%)$ & 42 (24.0\%) & & $0.81(0.48-1.39)$ & 0.449 \\
\hline & & $\mathrm{TT}$ & $5(4.1 \%)$ & $4(2.3 \%)$ & & $0.53(0.14-2.06)$ & 0.36 \\
\hline Log-additive & & - & - & - & & $1.28(0.82-1.99)$ & 0.27 \\
\hline
\end{tabular}


Analysis of haplotype association with $\mathrm{ICH}$ risk in patients with BAVMs

The reconstructed LD plot of the nine SNPs in the 333 controls was described in our previous report ${ }^{[16]}$. Three blocks were defined by the nine SNPs in VEGFA. Block 1 covered the region of VEGFA from the $5^{\prime}$ UTR to the first intron with a length of $2 \mathrm{~kb}$ (SNPs 2-3). Block 2 extended $4 \mathrm{~kb}$ (SNPs 4-6) and encompassed the middle part of the gene from intron 2 to intron 5. Block 3 contained the terminal section of the gene, ranging mainly from intron 7 to the $3^{\prime}$ UTR (SNPs 7-9, size=1 $\mathrm{kb})$. The overall distribution of haplotypes in block 2 was significantly different between unruptured cases and ICH cases (Table 3). Haplotype-specific analysis revealed the haplotype 'GC' in block $1\left(P_{\text {sim }}=0.033\right)$ and the haplotype 'ACC' in block $2\left(P_{\text {sim }}=0.005\right)$ correlated with a significant protective effect against $\mathrm{ICH}$ risk in patients with BAVMs (adjusted $\mathrm{OR}=0.70$; 95\% CI=0.49-1.02 and adjusted $\mathrm{OR}=0.62,95 \% \mathrm{CI}=0.4-0.93$, respectively) compared to the most common haplotype.

\section{Association analysis with stratification}

We further evaluated whether the rs1547651 variant and haplotype 'ACC' in block 2 were associated with ICH risk in patients with BAVMs, as stratified by age, sex, BAVM size and venous drainage status. As shown in Table 4, compared with the common wild-type homozygous genotype, the increased risk associated with genotype AT of rs1547651 was more pronounced in female subjects (adjusted OR=3.21, 95\% $\mathrm{CI}=0.99-10.36)$. Moreover, the protective effect of haplotype 'ACC' in block 2 was more evident in males and subjects with BAVMs of a size $\geq 3 \mathrm{~cm}$ (adjusted OR=0.57, 95\% CI=0.34-0.97 and adjusted $\mathrm{OR}=0.57,95 \% \mathrm{CI}=0.31-0.86$, respectively).

\section{Discussion}

VEGFA has the ability to increase vascular permeability and cause vasodilatation, and it has been shown to be associated with various hemorrhagic disorders. Overexpression of VEGFA was reported recently in patients with brain tumorassociated $\mathrm{ICH}^{[23]}$. In this study, we reported the association between multiple common VEGFA polymorphisms and the hemorrhagic risk of BAVMs in a Han Chinese population. We found that one SNP out of nine selected SNPs showed a significant association with ICH risk. Moreover, haplotype analyses revealed that the haplotype ' $G C^{\prime}$ in block 1 ( $\left.P_{\text {sim }}=0.033\right)$, and the haplotype 'ACC' in block $2\left(P_{\text {sim }}=0.005\right)$ showed a decreased $\mathrm{ICH}$ risk in patients with BAVMs compared with those of the common haplotype. Our findings suggested that VEGFA gene variants might contribute to an increased $\mathrm{ICH}$ risk in patients with BAVMs.

Genetic variants within the conventional regulatory region, such as the 5' UTR and the 3' UTR, were analyzed as a priority in several previous studies. rs1547651, which is located in the promoter region, was reported to be significantly associated with bladder cancer; moreover, the TT genotype was linked to a three-fold increased risk for bladder cancer ${ }^{[24]}$. In our study, the heterozygous genotype was significantly associated with increased ICH risk (adjusted OR=2.11, 95\% CI $=1.01-4.42$ ) compared with the AA genotype. Moreover, our stratified analyses revealed that the AT genotype had a threefold increased risk of ICH compared with the AA genotype in females (adjusted OR=3.21, 95\% CI=0.99-10.36). Despite the fact that the single SNP association of rs1547651 was not significant after using the stringent Bonferroni correction, the association might still be noteworthy. Using the TFSEARCH

Table 3. Frequency of the distribution of haplotypes in the VEGFA gene and their association with risk of hemorrhagic presentation.

\begin{tabular}{|c|c|c|c|c|c|c|c|c|c|c|}
\hline Block & Haplotype $^{\mathrm{a}}$ & Total & $\mathrm{ICH}$ & (\%) & Unruptured & (\%) & $P$ value & $P_{\text {sim }}$ value $^{\mathrm{b}}$ & $\begin{array}{l}\text { Adjusted OR } \\
\qquad(95 \% \mathrm{Cl})^{\mathrm{c}}\end{array}$ & $P$ value $^{\mathrm{C}}$ \\
\hline \multirow[t]{4}{*}{ Block 1} & $\mathrm{CC}$ & 277 & 168 & 46.4 & 109 & 41.9 & 0.277 & 0.283 & 1.00 (reference) & \\
\hline & $\mathrm{GC}$ & 199 & 103 & 28.5 & 96 & 36.9 & 0.030 & 0.033 & $0.70(0.49-1.02)$ & 0.063 \\
\hline & $\mathrm{GA}$ & 146 & 91 & 25.1 & 55 & 21.2 & 0.288 & 0.324 & $1.09(0.72-1.65)$ & 0.692 \\
\hline & Global-stat $=4.79$ & & & $d f=2$ & & $P=0.091$ & & $P_{\text {sim }}{ }^{b}=0.089$ & & \\
\hline \multirow{3}{*}{ Block 2} & $\mathrm{ACC}$ & 141 & 69 & 19.1 & 72 & 27.7 & 0.007 & 0.005 & $0.62(0.41-0.93)$ & 0.020 \\
\hline & Others $^{d}$ & 36 & 25 & 6.9 & 11 & 4.2 & 0.243 & 0.231 & $1.43(0.68-3.07)$ & 0.341 \\
\hline & Global-stat $=9.32$ & & & $d f=4$ & & $P=0.054$ & & $P_{\text {sim }}{ }^{b}=0.043$ & & \\
\hline \multirow[t]{2}{*}{ Block 3} & GCC & 428 & 252 & 69.8 & 176 & 67.7 & 0.662 & 0.665 & 1.00 (reference) & \\
\hline & $\mathrm{CCT}$ & 100 & 51 & 14.1 & 49 & 18.8 & 0.105 & 0.117 & $0.75(0.48-1.17)$ & 0.202 \\
\hline
\end{tabular}

${ }^{\text {a }}$ Polymorphic bases were in 5'-3' order, as listed in Table 2. Loci chosen for block 1: SNPs 2-3, Loci chosen for block 2: SNPs 4-6, Loci chosen for block 3: SNPs 7-9.

${ }^{\mathrm{b}}$ Generated by permutation test with 10000 times simulation.

${ }^{\mathrm{c}}$ Adjusted for age and gender.

${ }^{\mathrm{d}}$ Haplotypes with a frequency of less than 0.1 were pooled into one mixed group. 
Table 4. Stratified analyses of the associations between the VEGFA rs 1547651 genotypes and haplotypes in block 2 with risk of hemorrhagic presentation by selected variables.

\begin{tabular}{|c|c|c|c|c|c|c|c|c|}
\hline \multirow{3}{*}{ Variables } & \multicolumn{4}{|c|}{ rs1547651 } & \multicolumn{4}{|c|}{ Block2 } \\
\hline & \multicolumn{2}{|c|}{ Unruptured/ICH } & \multicolumn{2}{|c|}{ OR $(95 \% \mathrm{Cl})^{\mathrm{a}}$} & \multicolumn{2}{|c|}{ Unruptured/ICH } & \multicolumn{2}{|c|}{ OR $(95 \% \mathrm{Cl})^{\mathrm{a}}$} \\
\hline & AA № $(\%)$ & AT № $(\%)$ & AA & AT & GCT № (\%) & ACC № (\%) & GCT & ACC \\
\hline \multicolumn{9}{|l|}{ Age at diagnosis } \\
\hline$>30$ & $\begin{array}{l}63(87.5) / \\
68(81.9)\end{array}$ & $\begin{array}{c}7(9.7) / \\
15(18.1)\end{array}$ & 1.00 (reference) & $1.96(0.74-5.15)$ & $\begin{array}{l}61(42.4) / \\
77(46.4)\end{array}$ & $\begin{array}{l}42(29.2) / \\
32(19.3)\end{array}$ & 1.00 (reference) & $0.59(0.33-1.05)$ \\
\hline$<=30$ & $\begin{array}{l}52(89.7) / \\
81(82.7)\end{array}$ & $\begin{array}{c}4(6.9) / \\
15(15.3)\end{array}$ & 1.00 (reference) & $2.42(0.76-7.73)$ & $\begin{array}{l}50(43.1) / \\
97(49.5)\end{array}$ & $\begin{array}{l}30(25.9) / \\
37(18.7)\end{array}$ & 1.00 (reference) & $0.66(0.37-1.20)$ \\
\hline \multicolumn{9}{|l|}{ Gender } \\
\hline Female & $\begin{array}{l}44(88.0) / \\
63(78.8)\end{array}$ & $\begin{array}{c}4(8.0) / \\
17(21.3)\end{array}$ & 1.00 (reference) & $3.21(0.99-10.36)$ & $\begin{array}{l}43(43.0) / \\
75(46.0)\end{array}$ & $\begin{array}{l}27(27.0) / \\
30(18.8)\end{array}$ & 1.00 (reference) & $0.68(0.35-1.29)$ \\
\hline Male & $\begin{array}{l}71(88.8) / \\
86(85.1)\end{array}$ & $\begin{array}{c}7(8.8) / \\
13(12.9)\end{array}$ & 1.00 (reference) & $1.53(0.58-4.04)$ & $\begin{array}{l}68(42.5) / \\
99(49.0)\end{array}$ & $\begin{array}{l}45(28.1) / \\
39(19.3)\end{array}$ & 1.00 (reference) & $0.57(0.34-0.97)$ \\
\hline \multicolumn{9}{|l|}{ BAVM size } \\
\hline$<3 \mathrm{~cm}$ & $\begin{array}{l}17(89.5) / \\
66(79.5)\end{array}$ & $\begin{array}{c}2(10.5) / \\
15(18.1)\end{array}$ & 1.00 (reference) & $2.11(0.43-10.35)$ & $\begin{array}{l}16(42.1) / \\
79(47.6)\end{array}$ & $\begin{array}{c}9(23.7) / \\
36(21.7)\end{array}$ & 1.00 (reference) & $0.90(0.36-2.28)$ \\
\hline$\geq 3 \mathrm{~cm}$ & $\begin{array}{l}98(88.3) / \\
83(84.7)\end{array}$ & $\begin{array}{c}9(8.1) / \\
15(15.3)\end{array}$ & 1.00 (reference) & $1.95(0.80-4.72)$ & $\begin{array}{l}95(42.8) / \\
95(48.5)\end{array}$ & $\begin{array}{l}63(28.4) / \\
33(16.8)\end{array}$ & 1.00 (reference) & $0.52(0.31-0.86)$ \\
\hline \multicolumn{9}{|c|}{ Venous drainage } \\
\hline Exclusively deep & $\begin{array}{l}23(92.0) / \\
86(79.6)\end{array}$ & $\begin{array}{c}2(8.0) / \\
20(18.5)\end{array}$ & 1.00 (reference) & $2.88(0.62-13.4 .2)$ & $\begin{array}{c}22(44.0) / \\
104(48.1)\end{array}$ & $\begin{array}{l}13(26.0) / \\
40(18.5)\end{array}$ & 1.00 (reference) & $0.63(0.29-1.40)$ \\
\hline Any superficial & $\begin{array}{l}92(87.6) / \\
63(86.3)\end{array}$ & $\begin{array}{c}9(8.6) / \\
10(13.7)\end{array}$ & 1.00 (reference) & $1.52(0.58-4.01)$ & $\begin{array}{l}89(42.4) / \\
70(47.9)\end{array}$ & $\begin{array}{l}59(28.1) / \\
29(19.9)\end{array}$ & 1.00 (reference) & $0.62(0.36-1.06)$ \\
\hline
\end{tabular}

${ }^{\mathrm{a}}$ Adjusted for age and gender.

program (http://mbs.cbrc.jp/research/db/TFSEARCH.html), we found that two possible transcriptional factors, GATA-1 and GATA-3, could bind to the A allele of rs1547651. We hypothesized that this polymorphism variation may affect the expression of VEGFA by changing the binding affinity of factors to the mRNA.

Increasing evidence indicates the importance of intronic VEGFA polymorphisms as markers of disease susceptibility $^{[24-26]}$. One Canadian study suggested that rs3025030 was associated with a higher risk of retinopathy. In our study, the genotype distribution of rs3025030 was significantly different between cases and controls $(P=0.047)$. Furthermore, no association was found via logistic regression analyses after adjustment for age and sex. Although the variants of rs3025030 were predicted to cause changes in the binding sites of transcription factors, which may result in the dysfunction of VEGFA expression using FASTSNP ${ }^{[27]}$, the effects of this variant needed to be validated in further studies.

Because we were confident that haplotype-based analysis is more powerful than single-marker analysis ${ }^{[28,29]}$, we performed this type of analysis to elucidate which haplotype was associated with an increased or a diminished risk of ICH. Although a few studies have been conducted regarding the involvement of VEGFA haplotypes in certain diseases ${ }^{[30-32]}$, the haplotypes analyzed in those studies are not comparable with ours because they genotyped different SNPs. In our study, we found that the 'GC' haplotype in block 1 and the 'ACC' haplotype in block 2 were significantly associated with $\mathrm{ICH}$ risk (adjusted $\mathrm{OR}=0.70,95 \% \mathrm{CI}=0.49-1.02, P_{\text {sim }}=0.033$ and adjusted $\mathrm{OR}=0.62,95 \% \mathrm{CI}=0.41-0.93, P_{\text {sim }}=0.005$, respectively); moreover, we observed a protective effect of the haplotype 'ACC' derived from rs833069, rs3024994, and rs3025010 in females and those with BAVMs of a size $\geq 3 \mathrm{~cm}$. We did not, however, see an independent association with the individual SNP present in the haplotype associated with ICH risk. Our hypothesis is that a combined haplotype, rather than a single SNP, is important for ICH.

Despite the fact that our study has several strengths, including a haplotype-based design and a homogeneous population of the same ethnicity, some inherent limitations must be noted. Some selection bias due to hospital-based controls cannot be ruled out. To limit the potential selection bias, we recruited patients by matching the controls to the individuals with BAVMs on the categories of age, sex and residential area. Only nine out of the exhaustive list of SNPs in VEGFA were genotyped in this study, and therefore, it is possible that we did not fully capture or represent the genetic variability of the gene; however, SNPs with high priority were selected for this 
study based on a careful review of previous functional analyses and association studies of VEGFA variation.

In conclusion, the results from our case-control study in a Chinese population suggest that the genetic variants of the VEGFA gene may modulate ICH risk in patients with BAVMs. In particular, we found two haplotypes with a significantly protective effect with respect to ICH risk in patients with BAVMs. Large-scale studies with ethnically diverse populations and functional evaluation of these studies are warranted to confirm our findings.

\section{Acknowledgements}

This study was supported by the National Natural Science Foundation of China (№ 30500524, 30973103, 81070936, 30800622, and 81001114), and the Scientific Research Foundation for the Returned Overseas Chinese Scholars.

\section{Author contribution}

Dr Hong-yan CHEN and Dr Yao ZHAO designed the research and revised the paper; Zhi-ping GONG conducted the experiments and wrote the paper; Ni-dan QIAO, Yu-xiang GU, Jian-ping SONG, Pei-liang LI, and Hui-jia QIU performed the experiments; Wei-wei FAN analyzed the data; and Ying MAO designed the research.

\section{References}

1 Arteriovenous Malformation Study Group. Arteriovenous malformations of the brain in adults. N Engl J Med 1999; 340: 1812-8.

2 Pawlikowska L, Tran MN, Achrol AS, McCulloch CE, Ha C, Lind DL, et al. UCSF BAVM Study Project: Polymorphisms in genes involved in inflammatory and angiogenic pathways and the risk of hemorrhagic presentation of brain arteriovenous malformations. Stroke 2004; 35 : 2294-300.

3 Connolly DT, Heuvelman DM, Nelson R, Olander JV, Eppley BL, Delfino $\mathrm{JJ}$, et al. Tumor vascular permeability factor stimulates endothelial cell growth and angiogenesis. J Clin Invest 1989; 84: 1470-8.

4 Ferrara N, Davis-Smyth T. The biology of vascular endothelial growth factor. Endocr Rev 1997; 18: 4-25.

5 Ferrara N. Role of vascular endothelial growth factor in regulation of physiological angiogenesis. Am J Physiol Cell Physiol 2001; 280 : C1358-66.

6 Bates DO, Harper SJ. Regulation of vascular permeability by vascular endothelial growth factors. Vascul Pharmacol 2002; 39: 225-37.

7 Ferrara N. Vascular endothelial growth factor as a target for anticancer therapy. Oncologist 2004; 9: 2-10.

8 Hashimoto T, Lawton MT, Wen G, Yang GY, Chaly T Jr, Stewart CL, et al. Gene microarray analysis of human brain arteriovenous malformations. Neurosurgery 2004; 54: 410-23.

9 Lee CZ, Xue Z, Zhu Y, Yang GY, Young WL. Matrix metalloproteinase-9 inhibition attenuates vascular endothelial growth factor-induced intracranial hemorrhage. Stroke 2007; 38: 2563-8.

10 Sfar S, Hassen E, Saad H, Mosbah F, Chouchane L. Association of VEGF genetic polymorphisms with prostate carcinoma risk and clinical outcome. Cytokine 2006; 35: 21-8.

11 Howell WM, Bateman AC, Turner SJ, Collins A, Theaker JM. Influence of vascular endothelial growth factor single nucleotide polymorphisms on tumour development in cutaneous malignant melanoma. Genes Immun 2002; 3: 229-32.
12 Kataoka N, Cai Q, Wen W, Shu XO, Jin F, Gao YT, et al. Populationbased case-control study of VEGF gene polymorphisms and breast cancer risk among Chinese women. Cancer Epidemiol Biomarkers Prev 2006; 15: 1148-52.

13 Lee SJ, Lee SY, Jeon HS, Park SH, Jang JS, Lee GY, et al. Vascular endothelial growth factor gene polymorphisms and risk of primary lung cancer. Cancer Epidemiol Biomarkers Prev 2005; 14: 571-5.

14 Awata T, Inoue K, Kurihara S, Ohkubo T, Watanabe M, Inukai K, et al. A common polymorphism in the $5^{\prime}$-untranslated region of the VEGF gene is associated with diabetic retinopathy in type 2 diabetes. Diabetes 2002; 51: 1635-9.

15 Vannay A, Dunai G, Bányász I, Szabó M, Vámos R, Treszl A, et al. Association of genetic polymorphisms of vascular endothelial growth factor and risk for proliferative retinopathy of prematurity. Paediatr Res 2005; 57: 396-8.

16 Chen HY, Gu YX, Wu WT, Chen D, Li PL, Fan WW, et al. Vascular endothelial growth factor $\mathrm{A}$ gene polymorphisms and susceptibility to sporadic brain arteriovenous malformations in a Chinese population. J Clin Neurosci 2011; 18: 549-53.

17 Joint Writing Group of the Technology Assessment Committee American Society of Interventional and Therapeutic Neuroradiology; Joint Section on Cerebrovascular Neurosurgery a Section of the American Association of Neurological Surgeons and Congress of Neurological Surgeons; Section of Stroke and the Section of Interventional Neurology of the American Academy of Neurology, Atkinson RP, Awad IA, Batjer HH, Dowd CF, Furlan A, Giannotta SL, et al. Reporting terminology for brain arteriovenous malformation clinical and radiographic features for use in clinical trials. Stroke 2001; 32: $1430-42$.

18 Jurinke C, van den Boom D, Cantor CR, Koster H. Automated genotyping using the DNA MassArray technology. Methods Mol Biol 2002; 187: 179-92.

19 Akaike $\mathrm{H}$. A new look at the statistical model identification. IEEE Trans Automat Contr 1974; 19: 716-23.

20 Lewontin RC. On measures of gametic disequilibrium. Genetics 1988; 120: 849-52.

21 Gabriel SB, Schaffner SF, Nguyen H, Moore JM, Roy J, Blumenstiel $\mathrm{B}$, et al. The structure of haplotype blocks in the human genome. Science 2002; 296: 2225-9.

22 Stephens M, Donnelly P. A comparison of Bayesian methods for haplotype reconstruction from population genotype data. Am J Hum Genet 2003; 73: 1162-9.

23 Jung S, Moon KS, Jung TY, Kim IY, Lee YH, Rhu HH, et al. Possible pathophysiological role of vascular endothelial growth factor (VEGF) and matrix metalloproteinases (MMPs) in metastatic brain tumorassociated intracerebral hemorrhage. J Neurooncol 2006; 76: 257 63.

24 García-Closas M, Malats N, Real FX, Yeager M, Welch R, Silverman $D$, et al. Large-scale evaluation of candidate genes identifies associations between VEGF polymorphisms and bladder cancer risk. PLoS Genet 2007; 3: e29.

25 Churchill AJ, Carter JG, Lovell HC, Ramsden C, Turner SJ, Yeung A, et al. VEGF polymorphisms are associated with neovascular age-related macular degeneration. Hum Mol Genet 2006; 15: 2955-61.

26 Al-Kateb H, Mirea L, Xie X, Sun L, Liu M, Chen H, et al. Multiple variants in vascular endothelial growth factor (VEGFA) are risk factors for time to severe retinopathy in type 1 diabetes: the DCCT/EDIC genetics study. Diabetes 2007; 56: 2161-8.

27 Yuan HY, Chiou JJ, Tseng WH, Liu CH, Liu CK, Lin YJ, et al. FASTSNP: an always up-to-date and extendable service for SNP function analysis and prioritization. Nucleic Acids Res 2006; 34: W635-41. 
28 Clark AG. The role of haplotypes in candidate gene studies. Genet Epidemiol 2004; 27: 321-33.

29 Han SW, Kim GW, Seo JS, Kim SJ, Sa KH, Park JY, et al. VEGF gene polymorphisms and susceptibility to rheumatoid arthritis. Rheumatology (Oxford) 2004; 43: 1173-7.

30 Churchill AJ, Carter JG, Lovell HC, Ramsden C, Turner SJ, Yeung A, et al. VEGF polymorphisms are associated with neovascular age-related macular degeneration. Hum Mol Genet 2006; 15: 2955-61.
31 Churchill AJ, Carter JG, Ramsden C, Turner SJ, Yeung A, Brenchley PE, et al. VEGF polymorphisms are associated with severity of diabetic retinopathy. Invest Ophthalmol Vis Sci 2008; 49: 3611-6.

32 Tsai SJ, Hong CJ, Liou YJ, Chen TJ, Chen ML, Hou SJ, et al. Haplotype analysis of single nucleotide polymorphisms in the vascular endothelial growth factor (VEGFA) gene and antidepressant treatment response in major depressive disorder. Psychiatry Res 2009; 169: 113-7. 